\title{
Correlation between systolic function and presence of myofibroblasts in doxorubicin-induced cardiomyopathy
}

\author{
Correlação entre função sistólica e presença de miofibroblastos \\ na cardiomiopatia induzida pela doxorrubicina
}

\author{
Fábio Nelson Gava ${ }^{I}$ Sheila Nogueira Saraiva da Silva ${ }^{I I}$ Fernando Azadinho Rosa ${ }^{\text {II }}$ \\ Edna Mireya Gómez Ortiz ${ }^{\text {II }}$ Bruno Cristian Rodrigues ${ }^{\text {II }}$ Márcio de Barros Bandarra ${ }^{\text {II }}$ \\ Rosemeri de Oliveira Vasconcelos ${ }^{\text {II }}$ Aparecido Antonio Camacho ${ }^{\text {II }}$
}

\section{ABSTRACT}

Cardiotoxicity induced by doroxubicin generates systolic disfunction and myocardial remodeling with presence of myofibroblasts. These cells are thought to be attracted to the injured heart to avoid the development of congestive heart failure. The objective of this study was to evaluate the systolic dysfunction generated by doxorubicin through Doppler echocardiography, and its correlation with the presence of myofibroblasts in the myocardium. Twenty-five New Zealand White rabbits were divided into two groups (control, and treated with doxorubicin). The drug was administered for six weeks; Doppler echocardiography was performed before the first, and after the last administration of doxorubicin. Immuno detection of myofibroblasts was performed by immunohistochemistry. The treated group exhibited significant reduction in systolic function as assessed by Doppler echocardiography, and increased frequency of myofibroblasts, which were present in similar amounts in the left ventricle, interventricular septum, and right ventricle. There was a significant negative correlation between number of myofibroblasts in the interventricular septum and in the left ventricle with systolic function indices, which reveals that the higher the number of fibroblasts, the worst systolic function is in rabbits treated with doxorubicin. Increase in myofibroblast numbers was not sufficient to preserve systolic function.

Key words: $\alpha-S M A$, doxorubicin, Doppler echocardiography, rabbits.

RESUMO

A cardiotoxicidade induzida pela doxorrubicina gera disfunção sistólica e remodelamento miocárdico, com presença de miofibroblastos. Acredita-se que essas células sejam atraídas para a não evolução do quadro de insuficiência cardiaca congestiva. $O$ objetivo do presente trabalho foi avaliar a função sistólica gerada pela doxorrubicina por meio da ecodopplercadiografia e correlacioná-la com a presença de miofibroblastos no miocárdio. Foram utilizados 25 coelhos da raça Nova Zelândia, alocados em dois grupos (controle e tratados com doxorrubicina). O fármaco foi administrado por seis semanas e a ecodopplercardiografia foi realizada no momento zero e após a última administração da doxorrubicina. A imunodetecção dos miofibroblastos foi realizada por imuno-histoquímica. Houve redução significativa na função sistólica, observada na ecodopplercardiografia e aumento na imundetecção dos miofibroblastos nos animais tratados, na mesma intensidade no ventrículo esquerdo, septo interventricular $e$ ventrículo direito. Houve correlação negativa significativa entre o número de miofibroblastos no septo interventricular e no ventrículo esquerdo com os índices de função sistólica, revelando que quanto mais miofibroblastos presentes, pior é a função sistólica de coelhos tratados com doxorrubicina. $O$ aumento do número de miofibroblastos não foi suficiente para manutenção da função sistólica.

Palavras-chave: $\alpha$-SMA, doxorrubicina, ecodopplercardiografia, coelhos.

\section{INTRODUCTION}

Doxorubicin can be used in experimental models to induce dilated cardiomyopathy owing to its known cardiotoxic effects. Doxorubicin is a chemotherapeutic drug widely used in oncological patients, and its cardiotoxicity is related to several cellular mechanisms, such as necrosis and apoptosis (GREEN \& LEEUWENBURGH, 2002). Such alterations result in cardiac dilation, loss of contractile

\footnotetext{
IFaculdade de Medicina de Ribeirão Preto, Universidade de São Paulo (USP), Av. Bandeirantes, 3900, Monte Alegre, 14049-900, Ribeirão Preto, SP, Brasil. E-mail: gavacardiovet@gmail.com. Corresponding author.

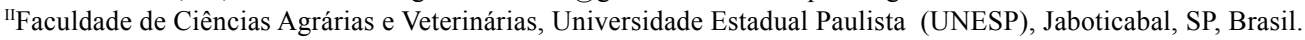

IIIUniversidade Federal de Uberlândia (UFU), Uberlândia, MG, Brasil.
} 
capacity, and remodeling of the cardiac muscle (TOYODA et al., 1998; TJEERDSMA et al., 1999).

After death of cardiomyocytes, a myocardial remodeling process begins, and the extracellular matrix (ECM) is the most affected compartment. Studies have demonstrated the participation of fibrillar collagen, fibronectin, and phenotypically transformed fibroblasts (myofibroblasts) on myocardial scarring. Changes in number and distribution of these structures affect myocardial complacence, with consequent alteration of systolic and diastolic function (HERPEL et al., 2006; FRANZ et al., 2010). Phenotypically transformed fibroblasts (myofibroblasts) are cells responsible for the production of fibronectin and collagen. Hence, an increase in number of myofibroblasts in the injured myocardium correlates with maintenance of myocardial complacence, which avoids rupture of the affected cardiac area (PESSANHA, et al., 1999; BERNI, et al., 2009).

Since myofibroblasts exhibited characteristics of fibroblasts and smooth muscle cells, their presence in the myocardium can be assessed by immunohistochemical detection of alpha smooth muscle actin ( $\alpha$-SMA). In the normal myocardium, the only cells that are positive for $\alpha$-SMA are vascular smooth muscle cells (PESSANHA, et al., 1999). Recent studies in dogs, humans, and laboratory animals have demonstrated the importance of myofibroblasts distribution in injured cardiac muscle for the evolution of heart failure, and as an improvement indicator for novel therapeutic methods yet to be tested (ZHANG et al., 1998; SWANEY et al., 2005; HAN, et al., 2008; ASAZUMA-NAKAMURA et al., 2009).

Accordingly, the aim of this research was to study the presence of myofibroblasts in doxorubicin-induced cardiomyopathy in rabbits through immunohistochemistry, and to correlate with Doppler echocardiography indices. Additionally, a comparison between myofibroblast presence in the left ventricle, interventricular septum and right ventricle was also performed.

\section{MATERIALS AND METHODS}

Animals

Twenty-five male New Zealand White rabbits weighing between 2.0 and $4.0 \mathrm{~kg}$ from a commercial rabbitry were used. Rabbits were kept in individual cages measuring $80 \mathrm{~cm} \times 50 \mathrm{~cm} \times 35 \mathrm{~cm}$, with commercial feed appropriate for this species and water ad libitum. Animals were randomly distributed into two experimental groups: control group (G1), with 10 rabbits, and treated group (G2), with 15 rabbits.

Induction of cardiomyopathy using doxorubicin Drug dilution was performed in a laminar flow hood $\left(\right.$ Filtracom $\left.^{\circledR}\right)$ suitable for handling chemotherapeutic drugs. None of the animals were anesthetized during drug administration. Initially, the fur on the ear was clipped, and skin was prepared aseptically. Venipuncture was performed using a 21-gauge scalp vein needle on the auricular vein, and the total dose of the diluted drug was slowly administered.

Animals in group G2 received $1 \mathrm{mg} / \mathrm{kg}$ of doxorubicin twice a week for six weeks, and animals in group G1 received only saline solution twice a week for six weeks. This protocol has been studied by our research group (GAVA et al., 2013).

Doppler echocardiography evaluation

Doppler echocardiographic examination was performed on day zero (T0), before the first treatment, and after the last administration of doxorubicin (T45). After clipping the fur on the thorax, animals were physically restrained in lateral recumbency, without anesthesia. For Doppler echocardiography, a Doppler ultrasound scanner (My Lab 30 Gold Vet) with a dual-frequency (7.5 and $10 \mathrm{MHz}$ ) transducer was used.

The following parameters were obtained: interventricular septum in end diastole (IVSED), left ventricular end-diastolic dimension (LVEDD), left ventricular free wall in end diastole (LVFWED), interventricular septum in end systole (IVSES), left ventricular end-systolic dimension (LVESD), and left ventricular free wall in end systole (LVFWES). Fractional shortening (FS) and ejection fraction (EF) (by Teichholz>s formula) were also calculated.

Euthanasia, sample collection and immunohistochemistry

Euthanasia of the animals was performed with sequential intravenous administration of propofol and potassium chloride; fragments of the myocardium were harvested immediately thereafter. Fragments of the right ventricle, interventricular septum and left ventricle were collected, fixed in 10\% phosphate buffered formalin at $\mathrm{pH} 7.6$, processed and embedded in paraffin.

For immunohistochemistry, endogenous peroxidase was quenched using hydrogen peroxide 
in methanol, and nonspecific protein binding was blocked using a commercial blocking solution (Protein Block, DAKO, X0909). Primary antibody incubation was performed in humid chamber for 18 hours at $4^{\circ} \mathrm{C}$. An anti- $\alpha$-SMA monoclonal antibody (DBS, MOB 001) was used at a dilution of 1:600. An antibody polymerized with horseradish peroxidase (Kit Advance HPR, Dako, K4068) was used as a secondary antibody. Diaminobenzidine chromogen (DAB, Dako, K3468) was used as a chromogen for reaction development. Counterstaining was performed using Harris Hematoxylin, which was followed by dehydration in alcohol and xylol solutions. As a negative control, the primary antibody was omitted from the reaction. Five random fields per slide were photographed, and the images were analyzed using Micrometrics software (MicrometricsTM SE Premium, version 2.8) to count the number of immunostained cells. The average number of immunostained cells in all five images of each slide was recorded.

\section{Statistical analysis}

Doppler echocardiographic parameter values on $\mathrm{T} 0$ and T45, and the number of myofibroblasts in each analyzed area were subjected to analysis of variance; means were compared using Tukey's test at a significance level of $5 \%$. The correlation between myofibroblast counts and Doppler echocardiografic parameters of systolic function (ejection fraction and fractional shortening) was analyzed using Pearson's correlation at a significance level of $5 \%$.

\section{RESULTS AND DISCUSSION}

There were no deaths in group G1 during the whole study period. The mortality rate in group $\mathrm{G} 2$ was $33 \%(n=5)$, and these animals were not evaluated by echocardiography or immunohistochemistry. The mortality indices reported in this study express the potential dose-dependent toxic effect of doxorubicin on rabbits. Administration of $1 \mathrm{mg} / \mathrm{kg}$ of doxorubicin twice a week proved to be safe and feasible, without high mortality rates, which allowed reliable assessments until the end of the experiment. This fact corroborates other a study in which doxorubicin was administered to rabbits (CHEN et al., 2010; GAVA et al., 2013).

Animal mortality in this study can be explained by the high toxicity potential of the drug for several organs. Myelosuppression, nephrotoxicity, and hepatotoxicity are other side effects that are determinants for using doxorubicin. Anthracyclines produce highly reactive free radicals that are capable of injuring cell membranes and DNA. Therefore, this drug can exert time- and dose-dependent toxicity on several organs (DIAS et al., 2003).

The data obtained by Doppler echocardiography (Table 1) highlighted the efficiency of this exam for detection of early alterations of doxorubicin-induced dilated cardiomyopathy in rabbits. These data revealed a decrease in systolic function after cumulative exposure to the drug. Functional alterations seen in the animals from the group treated with doxorubicin clearly showed that the cardiotoxic effect of this drug is dose-dependent. When the cumulative dose of the drug reached $12 \mathrm{mg}$ of doxorubicin $/ \mathrm{kg}$ at T45 (6 weeks), animals already exhibited alterations in systolic function parameters, with values below those established for the species (STYPMANN et al., 2007).

These findings showed the great sensitivity of the rabbit myocardium to doxorubicin exposure, and the quickness with which cardiomyopathy is induced in these animals, since they tolerate weekly administrations of the drug. The same occurred in a study performed in dogs (SOUZA \& CAMACHO, 2006); however, in that study, induction of cardiomyopathy required a longer period (12 weeks) because the drug can be administered only every 21 days in canines.

Myofibroblast counts are shown in table 2. Since smooth muscle cells expressed $\alpha$-SMA, animals from the control group exhibited strong staining from this antibody on vascular walls, and this immunostaining served as an internal positive control for antibody staining. Animals treated with doxorubicin, on the other way, exhibited high numbers of intensely labeled cells with elongated cytoplasm among the cardiomyocytes; these elongated cells were characterized as myofibroblasts (Figure 1). There was a significant difference in myofibroblast counts between animals treated with doxorubicin and animals in the control group. Comparisons between different regions of the heart did not reveal significant differences regarding myofibroblast counts.

Most studies describe histopathological alterations only on the left ventricle (TIDHOLM \& JÖNSSON, 2005). Data obtained in the present study allow us to infer that the frequency of myofibroblasts in similar in the three anatomical regions studied (right ventricle, interventricular septum, and left ventricle). This fact is in contrast with the histopathological 
Table 1 - Values of Doppler echocardiographic parameters (mean \pm SE) of rabbits during treatment with doxorubicin. UNESP, Jaboticabal, SP (2015).

\begin{tabular}{|c|c|c|c|}
\hline Parameters & . & E & 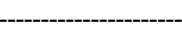 \\
\hline \multirow{3}{*}{ IVSES } & & T0 & $\mathrm{T} 45$ \\
\hline & G1 & $4.33 \pm 0.17 \mathrm{aA}$ & $4.95 \pm 0.36 \mathrm{aA}$ \\
\hline & G2 & $4.51 \pm 0.15 \mathrm{aA}$ & $4.19 \pm 0.17 \mathrm{aB}$ \\
\hline \multirow{2}{*}{ IVSED } & G1 & $3.13 \pm 0.12 \mathrm{aA}$ & $3.25 \pm 0.10 \mathrm{aA}$ \\
\hline & G2 & $3.42 \pm 0.07 \mathrm{aA}$ & $3.41 \pm 0.13 \mathrm{aA}$ \\
\hline \multirow{2}{*}{ LVESD } & G1 & $9.08 \pm 0.28 \mathrm{aA}$ & $9.16 \pm 0.47 \mathrm{aA}$ \\
\hline & G2 & $8.86 \pm 0.26 \mathrm{aA}$ & $10.25 \pm 0.44 \mathrm{bB}$ \\
\hline \multirow{2}{*}{ LVEDD } & G1 & $14.39 \pm 0.36 \mathrm{aA}$ & $14.76 \pm 0.51 \mathrm{aA}$ \\
\hline & G2 & $14.05 \pm 0.34 \mathrm{aA}$ & $13.05 \pm 0.53 \mathrm{aB}$ \\
\hline \multirow{2}{*}{ LVFWES } & G1 & $4.26 \pm 0.07 \mathrm{aA}$ & $4.37 \pm 0.09 \mathrm{aA}$ \\
\hline & G2 & $4.54 \pm 0.12 \mathrm{aA}$ & $3.45 \pm 0.14 \mathrm{bB}$ \\
\hline \multirow{2}{*}{ LVFWED } & G1 & $3.03 \pm 0.18 \mathrm{aA}$ & $3.07 \pm 0.13 \mathrm{aA}$ \\
\hline & $\mathrm{G} 2$ & $3.45 \pm 0.20 \mathrm{aA}$ & $3.35 \pm 0.08 \mathrm{aA}$ \\
\hline \multirow{2}{*}{ FS } & G1 & $37.06 \pm 0.83 \mathrm{aA}$ & $38.26 \pm 1.45 \mathrm{aA}$ \\
\hline & G2 & $36.82 \pm 0.92 \mathrm{aA}$ & $21.36 \pm 0.76 \mathrm{bB}$ \\
\hline \multirow{2}{*}{$\mathrm{EF}$} & G1 & $70.56 \pm 1.08 \mathrm{aA}$ & $71.86 \pm 1.73 \mathrm{aA}$ \\
\hline & G2 & $70.63 \pm 1.23 \mathrm{aA}$ & $47.14 \pm 1.34 \mathrm{bB}$ \\
\hline
\end{tabular}

G1: Control group; G2: Group treated with doxorubicin. IVSES: interventricular septum in end systole (mm); IVSED: interventricular septum in end diastole (mm); LVESD: left ventricular end-systolic dimension ( $\mathrm{mm})$; LVEDD: left ventricular end-diastolic dimension $(\mathrm{mm})$; LVFWES: left ventricular free wall in end systole $(\mathrm{mm})$; LVFWED: left ventricular free wall in end diastole (mm); FS: fractional shortening (\%); EF: ejection fraction (\%). Different lower case letters on the same line indicate significant difference ( $<<0.05)$ between time points. Different upper case letters in the same column indicate significant difference $(\mathrm{p}<0.05)$ between groups.

findings described by TOYODA et al. (1998) in dogs treated with doxorubicin, in which the right ventricle exhibited discrete alterations as compared to the left ventricle, and interventricular septum. A remodeling difference between ventricles also occurs in idiopathic dilated cardiomyopathy as demonstrated in the human myocardium, in which remodeling occurs differently in both ventricles during late stages of the disease (HERPEL et al., 2005).

These data reflect the importance of Doppler echocardiographic study of the right ventricle, since the findings in this research showed the existence of myocardial remodeling in this anatomical region after doxorubicin administration.

Table 2 - Mean values and standard errors of cells immunostained for $\alpha$-SMA (myofibroblasts) in rabbits after treatment with doxorubicin. UNESP, Jaboticabal, SP (2015).

\begin{tabular}{|c|c|c|c|c|}
\hline Antibody & -- & 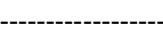 & egion----------- & 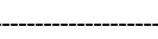 \\
\hline \multirow{3}{*}{$\alpha$-SMA } & & $\mathrm{RV}$ & IVS & LV \\
\hline & G1 & $0.26 \pm 0.09 \mathrm{aA}$ & $0.82 \pm 0.29 \mathrm{aA}$ & $0.91 \pm 0.39 \mathrm{aA}$ \\
\hline & G2 & $6.54 \pm 1.51 \mathrm{aB}$ & $5.72 \pm 1.39 \mathrm{aB}$ & $5.11 \pm 0.79 \mathrm{aB}$ \\
\hline
\end{tabular}

G1: Control group; G2: Group treated with doxorubicin; RV: Right ventricle; IVS: Interventricular septum; LV Left ventricle. Different lower case letters on the same line indicate significant difference $(\mathrm{p}<0.05)$ between regions. Different upper case letters in the same column indicate significant difference $(\mathrm{p}<0.05)$ between groups using Tukey's test. 


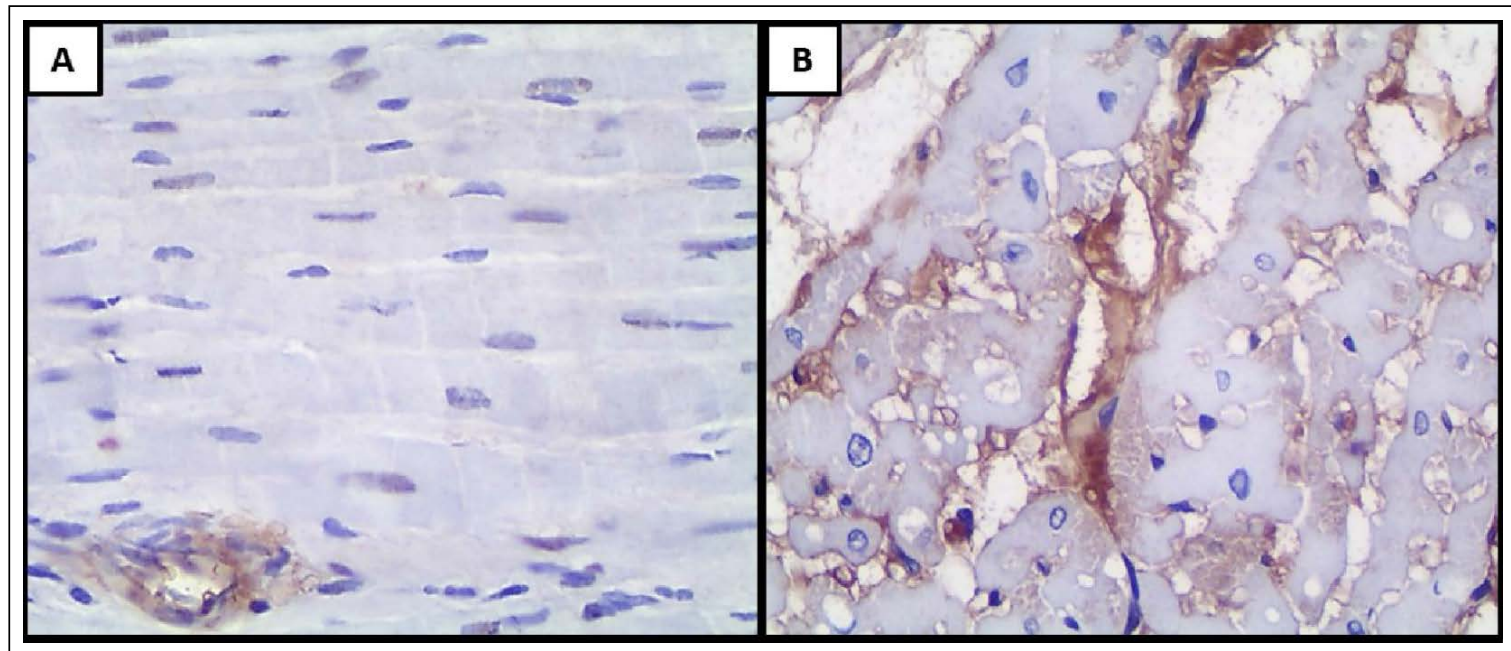

Figure 1 - Immunohistochemistry of the myocardium of rabbits. A: Interventricular septum of an animal from the control group: note $\alpha$-SMA labeling only around blood vessels (positive control, 40x magnification); B: Interventricular septum of an animal treated with doxorubicin: presence of myofibroblasts on the extracellular matrix (arrow/40x magnification); Method: Antibody polymerized with horseradish peroxidase (Advance).

However, this study is dependent on validations that are still being conducted in humans and animals (VITARELLI \& TERZANO, 2010).

Immuno detection of $\alpha$-SMA in the interventricular septum and left ventricle exhibited significant negative correlation with ejection fraction and fractional shortening, which reveals that as the number of myofibroblasts increases, systolic function decreases in rabbits treated with doxorubicin (Figure 2). This demonstrated the inability of the myofibroblasts to

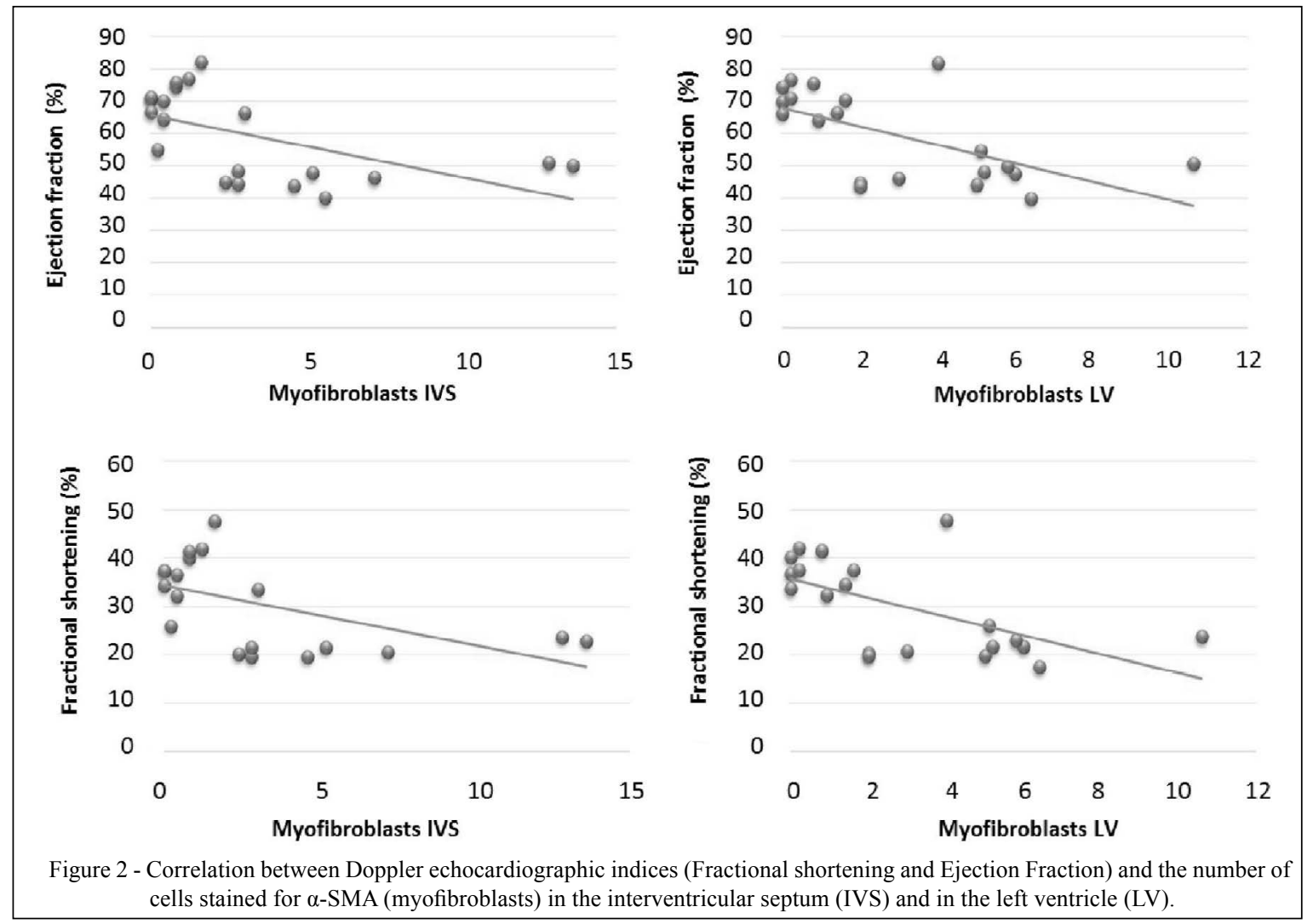

Ciência Rural, v.46, n.9, set, 2016. 
maintain systolic function in response to doxorubicin's toxic action. WILLEMS et al. (1994) suggested that the increase in number of myofibroblasts in myocardial lesions occurs as an attempt to maintain myocardial compliance, avoiding rupture of the affected area during cardiac contraction. However, this protective effect of myofibroblasts was not observed in this study, probably because the intensity of the lesion caused by doxorubicin surpassed the myocardial ability to sustain tissue repair at levels required for maintenance of systolic function.

\section{CONCLUSION}

Based on the results found in this study, it was conclude that myofibroblasts participated in the cardiac remodeling that ensues after administration of doxorubicin, and this participation occurs with the same intensity in the left ventricle, interventricular septum, and right ventricle. The increase in number of myofibroblasts in the myocardium was not sufficient to preserve systolic function in rabbits treated with doxorubicin.

\section{BIOETHICS AND BIOSSECURITY COMMITTEE APPROVAL}

The study was approved by the Ethics and Animal Welfare Committee at Faculdade de Ciências Agrárias e Veterinárias - Universidade Estadual Paulista (UNESP), Jaboticabal (protocol \# 5066-09).

\section{ACKNOWLEDGEMENTS}

The authors thank Fundação de Amparo à Pesquisa do Estado de São Paulo (FAPESP) for provision of financial support.

\section{REFERENCES}

ASAZUMA-NAKAMURA, Y. et al. $\mathrm{Cx} 43$ contributes to TGF- $\beta$ signaling to regulate differentiation of cardiac fibroblasts into myofibroblasts. Experimental Cell Research, v.315, p.11901199, 2009. Available from: <http://dx.doi.org/10.1016/j. yexcr.2008.12.021>. Accessed: Feb. 20, 2016. doi: 10.1016/j. yexcr.2008.12.021.

BERNI, R. et al. Modulation of actin isoform expression before the transition from experimental compensated pressure-overload cardiac hypertrophy to decompensation. American Journal of Physiology. Heart and Circulatory Physiology, v.296, p.1625-1632, 2009. Available from: <http://dx.doi.org/10.1152/ajpheart.01057.2008>. Accessed: Jan. 25, 2016. doi: 10.1152/ajpheart.01057.2008.

CHEN, Y. et al. Autologous bone marrow mesenchymal cell transplantation improves left ventricular function in a rabbit model of dilated cardiomyopathy. Experimental Molecular
Pathology, v.88, p.311-315, 2010. Available from: <http://dx.doi. org/10.1016/j.yexmp.2009.12.002>. Accessed: Jan. 21, 2016. doi: 10.1016/j.yexmp.2009.12.002.

DIAS, M.A. et al. Estudo de um modelo animal de hipoplasia sanguínea induzida pelo agente antineoplásico doxorrubicina (Adriblastina). Ars Veterinária, v.19, n.3, p.246-253, 2003.

FRANZ, M. et al. Changes in extra cellular matrix remodeling and re-expression of fibronectin and tenascin-C splicing variants in human myocardial tissue of the right atrial auricle: implications for a targeted therapy of cardiovascular diseases using human SIP format antibodies. Journal of Molecular Histology, v.41, p.39-50, 2010. Available from: <http://dx.doi.org/ 10.1007/s10735-010-9260-z >. Accessed: Dec. 10, 2015. doi: 10.1007/s10735-010-9260-z.

GAVA, F.N. et al. Doxorubicin induced dilated cardiomyopathy in a rabbit model: an update. Research in Veterinary Science, v.94, n.1, p.115-121, 2013. Available from: <http://dx.doi.org/ 10.1016/j.rvsc.2012.07.027>. Accessed: Nov. 15, 2015. doi: 10.1016/j.rvsc.2012.07.027.

GREEN, P.S.; LEEUWENBURGH, C. Mitochondrial dysfunction is an early indicator of doxorubicin-induced apoptosis. Biochimica et Biophysica Acta, v.1588, n.1, p.94-101, 2002.

HAN, R.I. et al. Distribution of myofibroblasts, smooth musclelike cells, macrophages, and mast cells in mitral valve leaflets of dogs with myxomatous mitral valve disease. American Journal of Veterinary Research, v.69, n.6, p.763-769, 2008. Available from: <http://dx.doi.org/10.2460/ajvr.69.6.763>. Accessed: Jan. 06, 2016. doi: 10.2460/ajvr.69.6.763.

HERPEL, E. et al. Extracellular matrix proteins and matrix metalloproteinases differ between various right and left ventricular sites in end-stage cardiomyopathies. Virchows Archives, n.446, p.369-378, 2005.

HERPEL, E. et al. Interstitial fibrosis in the heart: differences in extracellular matrix proteins and matrix metalloproteinases in end-stage dilated, ischaemic and valvular cardiomyopathy. Histopathology, v.48, n.6, p.736-747, 2006.

PESSANHA, M.G. et al. Reparação miocárdica quando em uso de baixa dosagem e longa duração de inibidor da síntese de óxido nítrico. Miofibroblastos, colágeno tipo III e fibronectina. Arquivos Brasileiros de Cardiologia, v.73, n.1, p.87-91, 1999.

SOUZA, R.C.A.; CAMACHO,A.A. Neurohormonal, hemodynamic, and electrocardiographic evaluations of healthy dogs receiving long-term administration of doxorubicin. American Journal of Veterinary Research, v.67, n.8, p.1319-1325, 2006.

STYPMANN, J.etal. Dopplerechocardiography and Tissue Doppler Imaging in the healthy rabbit: Differences of cardiac function during awake and anaesthetised examination. International Journal of Cardiology, v.115, p.164-170, 2007. Available from: $<$ http://dx.doi.org/doi:10.1016/j.ijcard.2006.03.006>. Accessed: Nov. 10, 2015. doi: 10.1016/j.ijcard.2006.03.006.

SWANEY, J.S. et al. Inhibition of cardiac myofibroblast formation and collagen synthesis by activation and overexpression of adenylyl cyclase. Proceedings of the National Academy of Sciences of the United States of America, v.102, n.2, p.437-442, 2005. Available 
from: <http://dx.doi.org/10.1073/pnas.0408704102>. Accessed: Nov. 10, 2015. doi: 10.1073/pnas.0408704102.

TIDHOLM, A.; JÖNSSON, L. Histologic characterization of canine dilated cardiomyopathy. Veterinary Pathology, v.42, p.1-8, 2005.

TJEERDSMA, G. et al. Early detection of anthracycline induced cardiotoxicity in asymptomatic patients with normal left ventricular systolic function: autonomic versus echocardiographic variables. Heart, v.81, n.4, p.419-423, 1999.

TOYODA, Y. et al. A canine model of cardiomyopathy induced by repetitive intracoronary doxorubicin administration. Journal of Thoracic and Cardiovascular Surgery, v.115, n.6, p.13671373, 1998 .
VITARELLI, A.; TERZANO, C. Do we have two hearts? New insights in right ventricular function supported by myocardial imaging echocardiography. Heart Failure Reviews, v.15, n.1, p.39-61, 2010. Available from: <http://dx.doi.org/10.1007/ s10741-009-9154-x>. Accessed: Jan. 06, 2016. doi: 10.1007/ s10741-009-9154-x.

WILLEMS, I.E. et al. The a-smooth muscle actin-positive cells in healing human myocardial scars. American Journal of Pathology, v.145, n.4, p.868-875, 1994.

ZHANG, J. et al. The expression of proliferating cell nuclear antigen and alpha smooth muscle actin in papillary muscles of the patient with rheumatic heart disease and its significance. Zhonghua yi xue za zhi, v.78, n.5, p.337-339, 1998. 